\title{
シクロスポリン投与マウスに损ける傍糸球体装置の変化
}

\begin{tabular}{|c|c|c|c|c|c|c|}
\hline 石川 & $\begin{array}{l}\text { 浜松 } \\
\text { 晃 }\end{array}$ & $\begin{array}{c}\text { 斗大学泌尿器科学 } \\
\text { 坂口 往子 }\end{array}$ & $\begin{array}{l}\text { (主任: } \\
\text { 中野 }\end{array}$ & 優 & 牛山 & 知已 \\
\hline 太田 & 信隆 & 大田原佳久 & 田島 & 惇 & 河邊 & 香月 \\
\hline
\end{tabular}

阿 曾 佳 郎

\section{CYCLOSPORINE INDUCED NEPHROTOXICITY AND JUXTAGLOMERULAR APPARATUS IN MICE}

\author{
Akira Ishikawa, Michiko Sakaguchi, Masaru Nakano, Tomomi Ushiyama, Nobutaka Ohta, \\ Yoshihisa Ohtawara, Atsushi Tajima and Kazuki Kawabe \\ Department of Urology, Hamamatsu University School of Medicine \\ (Chairman: Prof. Kazuki Kawabe) \\ Yoshio Aso
}

Department of Urology, Faculty of Medicine, The University of Tokyo

(Chairman: Prof. Yoshio Aso)

To elucidate the relationship between Cyclosporine $(\mathrm{Cs})$ induced nephrotoxicity and juxtaglomerular (JG) apparatus, we carried out biochemical and morphological experiments using mice.

Adult male ICR strain mice weighing about $40 \mathrm{~g}$ were used. The mice were divided into 2 groups: the Cs group (Cs $50 \mathrm{mg} / \mathrm{kg} /$ day was orally given for 14 consecutive days) and the control group (olive oil for 14 days). Urine was stored for 24 hours on the day 0,7 and 14 and urine volume and concentrations of urinary creatinine $(\mathrm{u}-\mathrm{Cr})$ and urinary potassium $(\mathrm{u}-\mathrm{K})$ were measured in each group. All the mice were sacrificed and examined on the 15th day. Concentrations of serum creatinine (s-Cr), serum potassium $(\mathrm{s}-\mathrm{K})$, plasma renin activity (PRA), plasma aldosterone (Ald) were noted in each group. The kidneys were also examined histologically with light and electron microscopes.

The Cs group showed significant increases of s-K, PRA and Ald and a significant decrease of creatinine clearance compared with the control group. Histologically, the Cs group demonstrated focal vacuolar changes in the proximal tubular cells and an increase in the number of granules in the JG cells.

Each granule of the Cs group was larger than that of the control group.

Cs certainly stimulates the renin-angiotensin-aldosterone system and causes consequently a secondary aldosteronism.

Key words: cyclosporine, juxtaglomerular apparatus, secondary aldosteronism

要旨：シクロスポリン（以下 Cs と略す）腎毒性による傍糸球体装置（以下 JGA と略す）の変化，レニ ンーアンギオテンシンーアルドステロン系 (以下 RAA 系之略す) の变化について実験的検討を行った.

動物は, ICR 系の成熟雄マウスを使用した。実験群は, Cs $50 \mathrm{mg} / \mathrm{kg} /$ 日, 14 日間経口投与群(以下 Cs 群と略す）と，オリーブ油14日間経口投与群（以下対照群と略す）の 2 群とした.

Cs 投与前， 7 日目，14日目にマウスの体重を記録するとともに24時間蓄尿し尿量，尿中クレアチニン， カリウムを測定した。 15 日目に屠殺採血し，血中クレアチニン，カリウム，レニン活性，アルドステロ ン値を測定した. 組織学的には, へマトキシリンーエオジン染色, Bowie 染色標本を光学影微鏡で観察 するとともに電子顕微鏡による観察を行った。

両群とも投与中の体重に有意な变化はなかった. Cs 群で血清カリウム, レニン活性, アルドステロン 
值の有意な上昇，クレアチニンクリアランスの有意な低下を認めた．組織学的検索では, Cs 群で近位尿 細管の focal な空胞变性と傍系球体細胞内顆粒の増大を認めた。

Cs 群で傍系球体細胞内顆粒は増大し, RAA 系は活性化されていた. Csにより続発性アルドステロン 症が惹起されると考えられた。

キーワード：シクロスポリン, 傍糸球体装置, 続発性アルドステロン症

\section{緒}

1985年に Bantle ら'は, シクロスポリン(以下 Cs と 略す）を使用した腎移植患者に，単なる腎機能の低下 だけでは説明できない血清カリウム $(\mathrm{S}-\mathrm{K})$ の上昇がみ られたと報告している，その原因について彼らは，レ ニン分泌障害に由来するアルドステロン分泌の低下， 尿細管のアルドステロン感受性の低下，これらによる 尿中カリウム排泄の低下が原因と述べている。

この報告をきっかけに我々は, Cs を用いた腎移植自 験例78例（生体腎39例, 死体腎39例) の移植後入院中 のデータを解析してみた。

その結果，移植腎針生検で Cs 腎毒性と診断された 28回のうち, 25回(89\%)は S-K の上昇を伴っていた2). 参考までに, 急性拒絶反応は44回で, その内 S-K が上 昇していたのは23回（52\%）であった。 S-Kの上昇に 関して，両者の間には有意な差が認められた（危険率 $1 \%$ 以下).レニンーアンギオテンシンーアルドステロ ン (RAA) 系についてはデータ数が少なく，一定の傾 向はつかめなかった。

以上の臨床上の知見をもとに, Cs による腎毒性時の $\mathrm{S}-\mathrm{K}$ 上昇の機序を解明するため, 今回 $\mathrm{Cs}$ 投与時の S$\mathrm{K} \cdot \mathrm{RAA}$ 系・傍系球体装置 $(\mathrm{JGA})$ の変化についてマ ウスを用いて実験的検討を行った。

\section{材料と方法}

実験には体重約 $40 \mathrm{~g}$ の ICR 系成熟雄マウスを使用 した. 実験群はCs 投与群 (Cs 群) と対照群の 2 群と し, 動物数は各群20匹とした。

ラットではなくマウスを用いたのは次の理由によ る. 高価な Cs がラットに比べて少ない量で斉み, しか も JGA の観察がラットに比べてマウスでは容易であ るからである。しかし，1匹のマウスから得られる血 清が約 $1 \mathrm{ml}$ と少なく, 量が不十分だったため, 結局同じ 条件で 2 回の実験を施行した。 2 回目は15日目の採血 のみ行い, レニン活性(PRA), アルドステロン(Ald) を測定した。

$\mathrm{Cs}$ 群の各マウスには, Cs の $5 \mathrm{mg} / \mathrm{ml}$ オリーブ油溶 液を用意し，1 日体重 $1 \mathrm{~kg}$ 当り $50 \mathrm{mg}, 14$ 日間連日胃管 を用いて経口投与した。対照群の各マウスには，溶媒
として用いたオリーブ油だけを14日間連日，胃管を用 いて経口投与した。

各群とも実験開始前, 開始後 7 日目, 14 日目の計 3 回24時間蓄尿を行い，尿量 (UV)，尿中クレアチニン (U-Cr)，尿中カリウム（U-K) をそれぞれ測定した.

Cs 投与終了後の 15 日目に, マウスの左大腿動静脈を 切断し採血を行った。血清クレアチニン (S-Cr), S-K, PRA, Ald を測定した。 特に PRA, Ald 測定用の検体 はへパリン採血とし, 3,000回転で15分間遠心分離後の 上清を $-70^{\circ} \mathrm{C}$ で涷結保存した。

$\mathrm{U}-\mathrm{Cr} \cdot \mathrm{S}-\mathrm{Cr}$ はアルカリ性ピクリン酸法で, U-K・S-K はイオン電極法で, PRA は RIA 固相法で, Ald は RIA 2 抗体法で，それぞれ測定した。

$\mathrm{UV} \cdot \mathrm{U}-\mathrm{Cr} \cdot \mathrm{S}-\mathrm{Cr}$ のデータが得られたマウスでクレ アチニンクリアランス (Ccr) を算出し, 両群間で比較 した。この内更に U-K・S-K む得られたマウスは, Fractional Excretion of Kalium（FEK）を算出し, 両群間で比較した。

組織学的には, ヘマトキシリンーエオジン $(\mathrm{HE})$ 染 色標本 (10\%ホルマリン液固定), Bowie 染色 ${ }^{3}$ 標本 (Helly 液 ${ }^{3}$ 固定)を光学顕微鏡で観察するとともに, 電 子顕微鏡による観察を行った。

結果の有意差検定には, student $\mathrm{T}$ 検定を用いた。

\section{結 果}

1）実験期間中のマウスの体重変化（図 1)

各群の実験期間中の体重変化を図 1 に示す.Cs 群の 投与終了時の体重は $38.5 \pm 2.6$ (平均値士標準偏差値) $\mathrm{g}$ であった．対照群の投与終了時の体重は $38.0 \pm 3.2 \mathrm{~g}$ であった。両群間に有意な差はなかった。

なお， 1 回目の実験で Cs 群 2 匹・対照群 4 匹，2 回 目の実験でCs 群 2 匹・対照群 1 匹のマウスが，それぞ れ途中で死亡した。経口投与時の誤嚥による肺炎・消 化管穿孔による腹膜炎が死亡の誘因であった。

2) S-Cr (図 2)

S-Crの測定結果を図 2 に示す.Cs群の S-Cr は $0.30 \pm 0.18 \mathrm{mg} / \mathrm{dl}$, 対照群の S-Cr は $0.20 \pm 0.18 \mathrm{mg} / \mathrm{dl}$ であった。両群間に有意な差はなかった。

3) S-K (困 2) 
困 1 投与期間中のマウスの体重の変化 $(m e a n \pm$ S.D. $)$

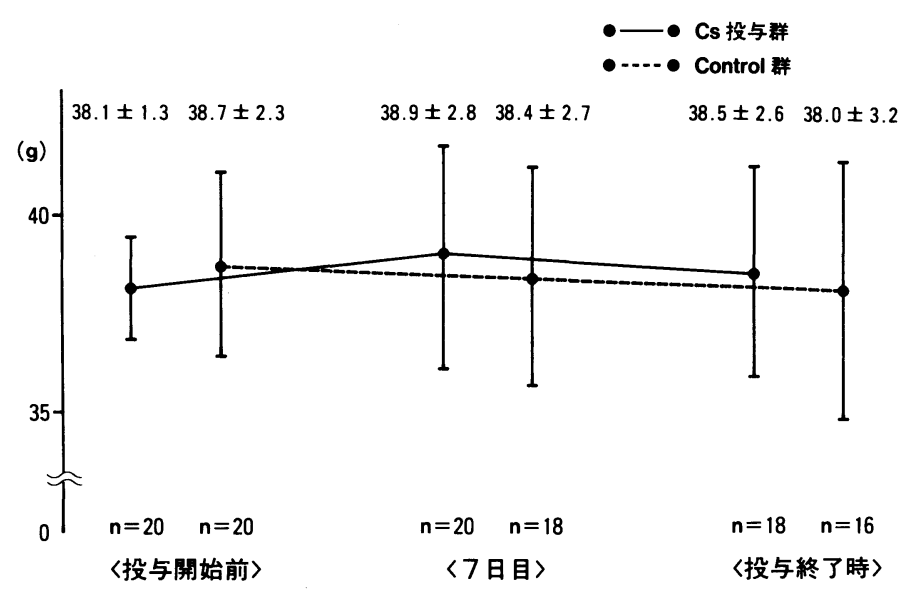

因 2 投与終了時の血液検查結果 $(m e a n \pm$ S.D. $)$
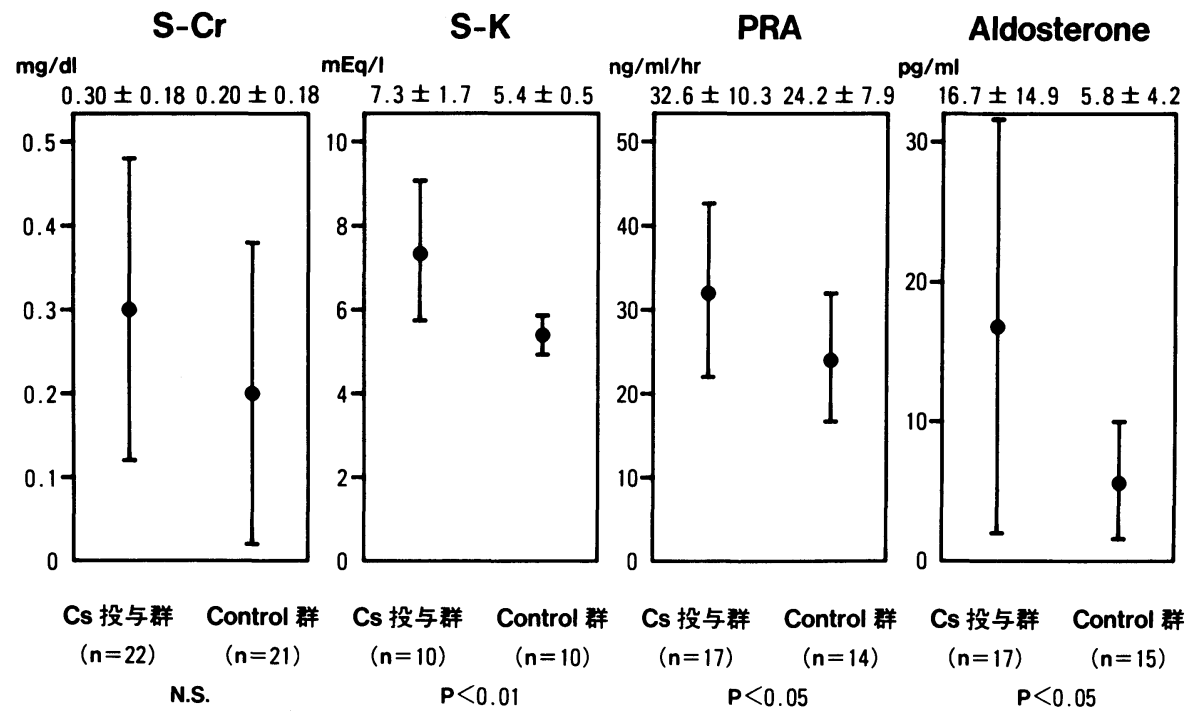

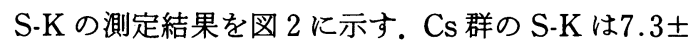
$1.7 \mathrm{mEq} / l$, 対照群の $\mathrm{S}-\mathrm{K} は 5.4 \pm 0.5 \mathrm{mEq} / l$ であっ た. Cs 群は対照群と比較して S-K が有意(危険率 $1 \%$ 以下）に上昇していた。

4) PRA（図 2)

PRA の測定結果を図 2 に示す.Cs 群の PRAは $32.6 \pm 10.3 \mathrm{ng} / \mathrm{ml} / \mathrm{hr}$, 対照群の PRA は24.2 $\pm 7.9 \mathrm{ng} /$ $\mathrm{ml} / \mathrm{hr}$ であった. Cs 群は対照群と比較して PRA が有 意（危険率 $5 \%$ 以下）に上昇していた。

5) Ald (図 2)

Ald の測定結果を図 2 に示す.Cs 群の Ald は16.7士
$14.9 \mathrm{pg} / \mathrm{ml}$, 対照群の Ald は5.8 $44.2 \mathrm{pg} / \mathrm{ml}$ であっ た. Cs 群は対照群と比較して Ald 值が有意（危険率 $5 \%$ \%下）に上昇していた。

6) Ccr (図 3 )

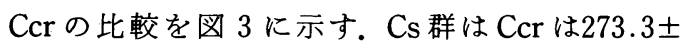
$164.3 \mathrm{ml} /$ 日, 対照群の Ccr は $488.0 \pm 280.9 \mathrm{ml} /$ 日で あった。 Cs 群は Ccr は対照群と比較して有意(危険率 $5 \%$ 以下）に低值を示した。

7) FEK (図 3)

FEK の比較を図 3 に示す. Cs 群のFEK は $0.00669 \pm 0.00485$, 対照群の FEK は $0.00442 \pm$ 
図 3 両群の Ccr・FEK の比較（mean \pm S.D.）

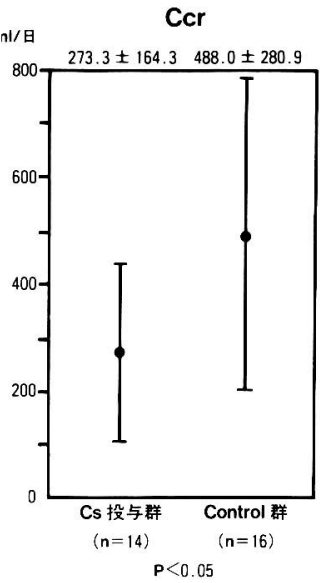

FEK

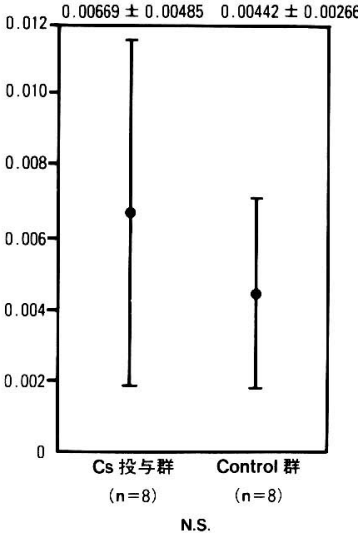

0.00266であった。両群間に有意差はなかった。

8) 組織所見（図 4, 5)

両群の Bowie 染色標本の光学顕微鏡像を図 4 K示 す.観察したCs 群のマウス18匹全てに, 対照群には認 められない. 1近位尿細管上皮細胞の focal な空胞変 性之, (2)傍系球体細胞 (JGC)内顆粒の増大が認められ た。
さらに, 電子顕微鏡下に JGC 内顆粒一つ一つの肥大 も観察された（図 5 ).

\section{考察}

実験の結果，S-K は予想された通り Cs 群で有意に 上昇していた. RAA 系は, Bantle らは抑制されると報 告している ${ }^{1)}$ ，我々の実験では逆に活性化されてい た. 現在，Cs 投与時の RAA 系の変化については，活 性化されるというのが多数を占める見解である4) 6). しかし，RAA が活性化される具体的な機序は不明で ある。

RAA 系の活性化は, 杀球体の輸入細動脈壁に存在 する JGCからのレニン分泌の増加に始まる7). レニン の分泌は, 主として JGCの圧感受機構により調節さ れ，輸入細動脈内圧が低下寸ると分泌が増加する7).

輸入細動脈内圧が低下する主な原因として，(1)循環 血液量の減少, (2)腎血流量の減少があげられる7). 循環 血液量が減少する原因には，大量の出血・発汗・水・ $\mathrm{Na}$ の摂取不足, 頻回の呕吐・下㢉等がある.ラットに $\mathrm{Cs} 50 \mathrm{mg} / \mathrm{kg} /$ 日を経口投与し，激しい下痢が起きたと いら報告8)，著明な体重減少を認めたという報告9) あ るが，今回の我々の実験では下痢は認めず，また実験 期間中のマウスの体重に有意な変化はなかった。

図 4 マウス腎のBowie 染色標本. Cs 群で近位尿細管の空胞变性が focal に認めら れる。交た，Cs 群では傍糸球体細胞内顆粒（矢印）が鮮明に観察できる.
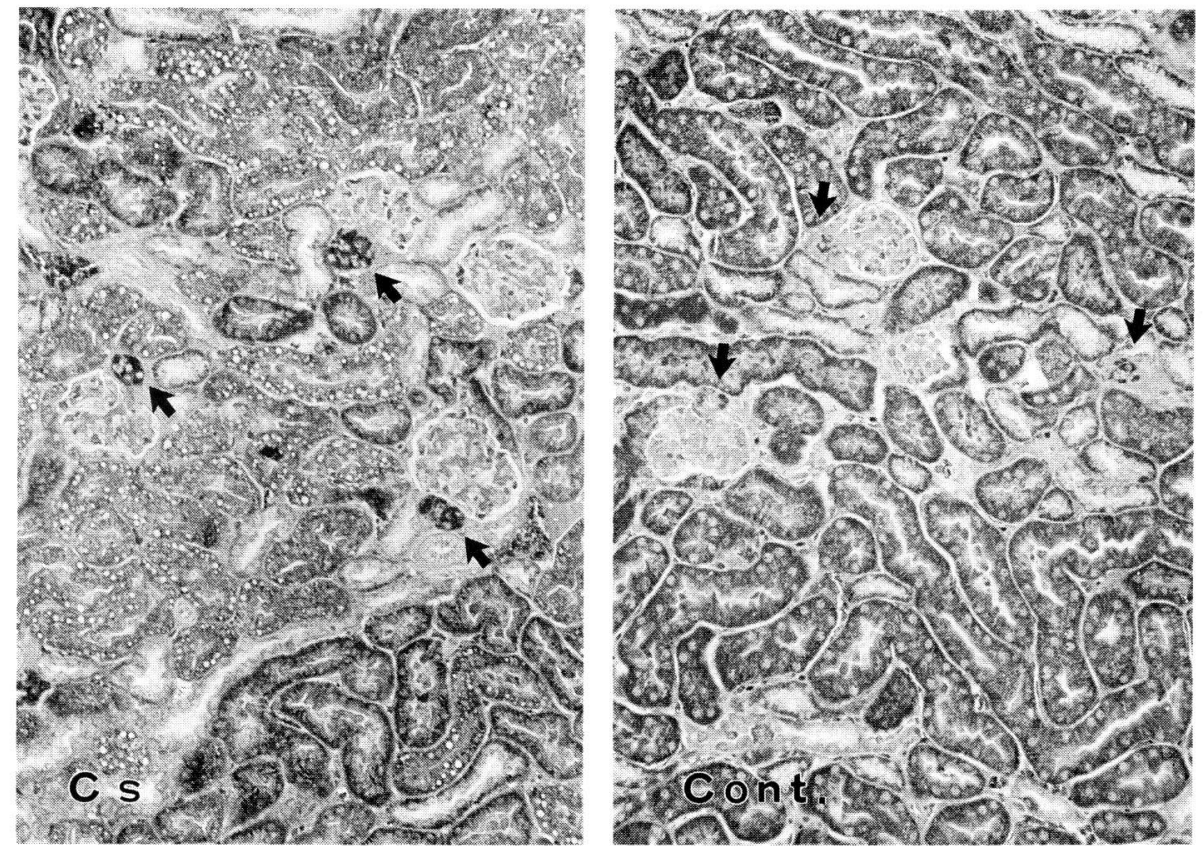
困 5 マウス腎の電子顕微鏡像. Cs 群の傍系球体細胞内顆粒は肥大している.

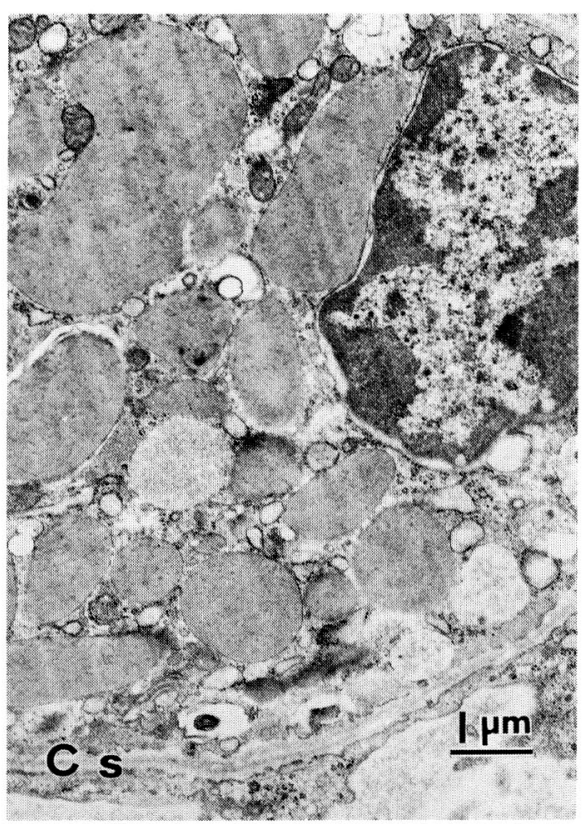

以上より，Cs 群で RAA 系が活性化された原因とし て, 循環血液量の減少よりはむしろ, 腎血流量の低下 の可能性が示唆される。しかし，今回の実験では組織 学的に腎血管系の異常は認められず，腎血流量の低下 を裏付ける証拠は得られていない.Cs 投与時の腎血流 量の变化についての検討が今後の課題である.

組織学的検索の結果 Cs 群で, (1)近位尿細管の focal な空胞変性の他に, (2) JGC内顆粒の増大が観察され た。我々が調べ得た限り, 増大した JGC 内顆粒を示し ている報告は見当たらない。

今回の実験で, Csにより続発性アルドステロン症が 惹起されることが判明した. Ald は尿中へのカリウム 排泄を促進し ${ }^{10)}$ ，乙の結果 S-K は低下寸る ${ }^{10)}$ ，ところ が，実験では Cs 群で Ald が有意に上昇していたにも かかわらず S-K は高值であった。この原因としては， 2 群間で FEK に有意な差がみられなかったことか

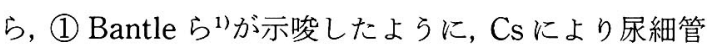
の Ald 感受性が低下し, その結果尿中カリウム排泄が 低下した可能性はある。また(2) Csにより尿細管のカ リウム排泄機能自体が障害され，その結果尿中カリウ ム排泄が低下したことも考えられる。

今回の実験で $\operatorname{Cs}$ の投与量・投与法は, 諸家の報 告8)911112)を参考にして $50 \mathrm{mg} / \mathrm{kg} /$ 日の 14 日間経口投与 とした.しかし, 実際の臨木での投与量は多くて16mg/

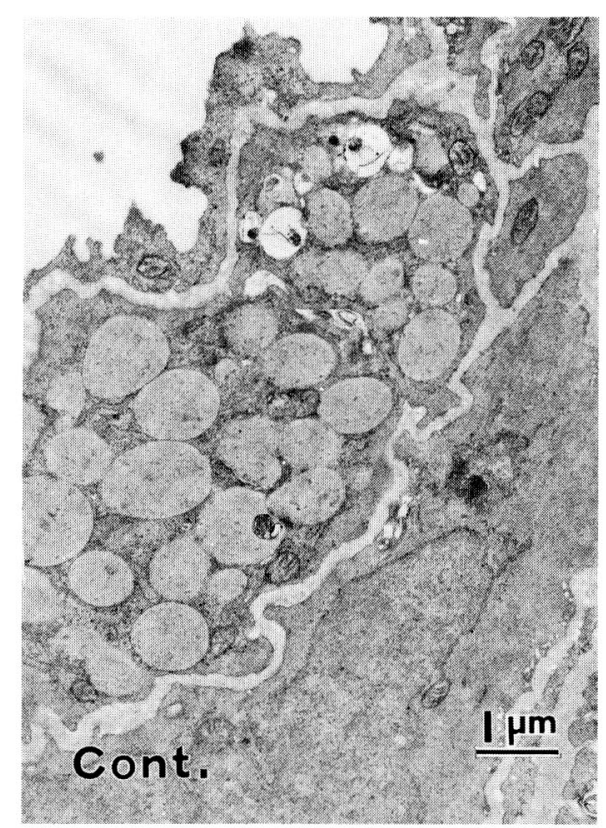

$\mathrm{kg} /$ 日である，臨床で生ずる変化にできるだけ近づけ るため, マウスへの Cs 投与量について検討を要する と考完られた。

\section{結語}

ICR 系マウスに, 1 日体重 $1 \mathrm{~kg}$ 当り $50 \mathrm{mg}$ の Cs 14 日間連日，胃管を用いて経口投与した。

その結果 RAA は活性化され, JGC 内顆粒は増大し ていた。Csにより続発性アルドステロン症が若起され ると考えられた。

本論文の要旨は, 報告者の一人, 石川 晃が第78回日本泌 尿器科学会総会（札幌, 1990) で発表した.

\section{文献}

1) Bantle, J.P., Nath, K.A., Sutherland, D.E.R., Naharian, J.S. and Ferris, T.F.: Effects of cyclosporine on the renin-angiotensinaldosterone system and potassium excretion in renal transplant recipients. Arch. Intern. Med., 145, 505-508, 1985.

2) 田島 嵉, 石川 茪, 寺田央巳, 森永聡一郎, 上田 大介, 麦谷荘一, 中野優, 中原正男, 畑昌宏, 牛山知已, 太田信隆, 大田原佳久, 鈴木和雄, 河邊 香月, 阿曾佳郎：拒絶反応の早期診断. 腎移植・血 管外科, 1, 14-24, 1989.

3) 西森一正：傍糸球体細胞顆粒の染色法. 臨床検查, 15, 445-449, 1971.

4) Perico, N., Zoja, C., Benigni, A., Bosco, E., 
Rossini, M., Morelli, C., Cattaneo, G.M. and Remuzzi, G.: Renin-angiotensin system and glomerular prostaglandins in early nephrotoxicity of ciclosporin. Contr. Nephrol., 51, 120-125, 1986.

5) Siegl, H., Ryffel, B., Petric, R., Shoemaker, P., Muller, A., Donatsch, P. and Mihatsch, M.: Cyclosporine, the renin-angiotensin-aldosterone system, and renal adverse reactions. Transplant. Proceedings, 15, 2719-2725, 1983.

6) Duggin, G.G., Baxter, C., Hall, B.M., Horvath, J. S. and Tiller, D.J.: Influence of cyclosporine A(CSA) on intrarenal control of GFR. Clinical Nephrology, 25, S43-S45, 1986.

7) 河野 剛：IV. 内分泌学的検查 H. その他血墏 $レ=$ ン活性(PRA)。日本臨床, 43，1108-1111，1985.
8）朴匀, 友吉唯夫, 野村康之, 岡部俊英: Ciclosporin の腎毒性に関する研究. 第 1 報. Ciclosporin 投与ラットに拈ける腎毒性について. 泌 尿紀要，33，1966-1974， 1987.

9）新村育夫, 両角國男, 吉田篤博, 及川 理, 藤波隆 夫, 打田和治, 高木 弘：シクロスポリンの腎毒性 に関する実験的検討. 移植, 20, 530-539, 1985.

10）藤本 守：電解質輸送機構/腎における電解質輸 送 $\mathrm{K}$ 輸送. 腎と透析，21，39-53， 1986.

11) Paller, M.S. and Murray, B.M. : Renal dysfunction in animal models of cyclosporine toxicity. Transpla. Proc., 17, 155-159, 1985.

12) Dieperink, H.: Cyclosporine A nephrotoxicity. Danish Medical Bulletin, 36, 235-248, 1989.

（1991年 5 月 14 日受理） 